\title{
Exploration on Cultivating Ethnic Minority Talents in Western Universities
}

\author{
Yanling Zheng \\ School of Preparatory Education for Nationlities, Ningxia University, Yinchuan, 750002, China
}

Keywords: University, Ethnic minority talents, Cultivation mode

\begin{abstract}
Western area of China has vast territory and large population. In recent years, with the rapid development of nationality education and improvement of the teaching quality, the high-level education has been improved. But the ethnic minority talents cultivation structure is still not reasonable. Regarding this problem, there should be more measurements to strengthen the cultivation of top-level talents. This article analyzes the reason of the demand for ethnic minority talents in western universities, and then explore and experiment of how to build multiple talent cultivation system and achieve the ethnic minority talent cultivation goal, so as to adapt to the social demand for multiple ethnic minority talents.
\end{abstract}

\section{The current situation and problem of ethnic minority talents cultivation in western universities}

\section{The current situation.}

National medium and long-term plan for education reform and development (2010-2010) has clearly pointed out to pay attention and support the ethnic minority education and to speed up the development. This has great significance to promote the social economic development in ethnic minority area, promote the joint hardworking for future prosperity of ethnic minority. As the populated area of ethnic minorities, Ningxia owns more than 35\% minority undergraduates in colleges and universities. As the main force to cultivating ethnic minority talents, universities in Ningxia and western area $s$ have faced with new goals and standards on how to cultivate ethnic minority talents under the new environment of the higher education.

The cultivation in western colleges.

It has always been an attention of various colleges and universities on how to improve the cultivation quality of ethnic minority talents. There are many reasons of the problems in ethnic minority graduates' employment. In a word, there are multiple interactive impacting from the government, schools, and student's individual irrational reasons leading to these problems. Analysis are as below:

\section{Large scale enrollment}

The annually continuous enrollment makes the number of undergraduates and graduates increase hugely in duplication. The number of graduates from normal colleges and universities in 2003 was 2.12 million. And reached 3.38 million in 2005, 6.31 million in 2010 and 7.49 million in 2015. We cannot deny that with the economic development, higher education should also get developed. Meanwhile, the demand and bearing capacity should be taken into account during the overall development. Blind pursuit of high speed would have passive influence especially on the employment of ethnic minority graduates. Now we are in the economic system transformation stage, main sectors receive huge numbers of graduates in the past such as the state-owned enterprises, government sectors and units have been through the structural reform limiting the recruitment scale, which has slowed down the increasing rate of the demand for labors. Under the case of increasing enrollment and reducing labor demand, ethnic minority graduates are undoubtedly facing difficulties.

The employment policy

With the deepening of the economic system reform since opening and reform, the market mechanism is playing a basic role in resource allocation. But right now the employment policy when ethnic minority students graduate is not matching the preferential policy when they are enrolled in colleges. Since 20 years after the resumption of university entrance examination, college entrance 
examination scores in Ningxia ethnic minorities still exist differences from 10 to 30. For Xinjiang Ethnic minorities, the scores even are between 150 to 200 without any change. (Considering some courses in the examination are draw up by itself, and the factor of student's subject constitute in scores, etc., the actual level is much more different.) In the survey, about $26.14 \%$ minority students feels the most difficult study problem is the poor foundation. The gap in fundamental education has led to the fact that Han nationality students and minority students enter school on two different standards. Then the school must apply two standard assessment and requirements to let them graduate from school according to two standards. After graduation, they get into the same talent market providing only one criterion cruelly to evaluate and recruit talents, which is making ethnic minority graduates harder to get employed.

\section{Students' dietary habit and religion.}

When students get graduated from school, they should consider whether or not they can get used to their dietary habit so that they have to give up the employer unit duo to the unconformity to own living requirement, which shortens the employment channels again.

\section{Talent competition and incentive mechanism is not well-developed.}

First, the incentive mechanism is not attractive enough. The seniority phenomenon is prevailing seriously in employment mechanism in western minority areas, which has heavily limited the talents development. In the promotion mechanism, there is no scientific judgment and evaluation for technological staff's achievement. They are often ignored or paid little attention by government because their achievement cannot bring direct economic effect. Second, the HR market operation is not reasonable enough. The service awareness in some talent markets in wester minority areas is very poor, and they even block related information not able to form open talent exchange mechanism.

\section{Unconformity between talent-selecting standards of employment unit and the cultivation goal of school.}

With the economic development, the employment units are setting higher and higher standard on ethnic minority talents. But there is huge gap between students' actual comprehensive quality and the requirements. Ethnic minority graduates cultivated by universities are good at professional knowledge but poor at practical working. Only by long-time training, they can meet the requirement of the employment unit selection standard, which will undoubtedly increase the unit's operation cost. The employment unit, as the investing party on human resource, they would consider the Investment appreciation of space on human capitals. From this perspective, the employment unit specially would give the work opportunities to those experienced job hunters, which is understandable. But this is exactly the bottleneck of the ethnic minority graduates' employment difficulties. The questionnaire surveys show that, enterprises pay the highest importance to the working experience.

We find out from graduates' experiences after job interview that, different employment units are showing different talents selection concepts. Some enterprises, especially the one which pays attention to ethnic minority graduates' fitting in specialty and present working experiences and abilities, will focus more on the evaluation on these aspects in the employment interview and have stricter standards. Results from the questionnaires also show that, about $36.4 \%$ of the enterprises think the best is "fitting the specialty", and $13.6 \%$ think "fitting the specialty" is the essential condition in talents selection. And the rest $14.1 \%$ will never hire students if not fitting the specialty. They also have high requirements on graduate's Chinese language level. The survey also shows that about $24.9 \%$ enterprises think Chinese language level is very important. $47.7 \%$ enterprises attach fair importance to it. Only $0.5 \%$ think it not important at all. This shows that the limitation of profession and Chinese language level has brought great difficulties to ethnic minority graduates in their employment. Also it indicates that some employers are too harsh on the specialty requirement, which is not good for their employment in relevant industries and this is inevitable leading to the narrow channels of employment.

At the same time, we can see problems in school education. Some companies are frank to tell us that there exist problems in talents cultuvation in colleges lacking practical processes and innovativ e education, which is not accordance with the social demand. The overall recognition on ethnic min ority graduates from employers are not high, which will definitely result in the "difficult employme 
nt in valid demands". The enterprise survey shows, only $0.9 \%$ companies are satisfied with minority graduates, $5 \%$ not satisfied and more than $48.6 \%$ of them give no anwser holding considerations.

\section{There are problems in school orientation of higher education.}

Firstly, there is little binding force of social recognition in the concept of talent cultivation in colleges. In the connection between planned economy and market economy, colleges are the field which is impacted little from the market crush. Because the supplied resources from higher education is far insufficient for satisfying the market demand of higher education, the college supply has the advantages. So far no matter how the effect of running a college is, there is no bankruptcy happening, making the university become the survival of the fittest in market economy. The limit from lacking competition pressure and the elimination mechanism of social recognition makes the loss of the testing standard of "serving the society" for the school to cultivate students. It leads to the students' unable to adapt to the social employment and also it cannot fundamentally put pressure to the college running. In addition, due to the shortage of teaching resources after enrollment, teachers must work hard beyond their capacity. Thus they cannot spend all their spirits in classroom teaching and curriculum research especially on ethnic minority students at the same time and perform very well, which finally leads to colleges' dissocialized and isolated running. This method of running schools will never nurture minority talent who can adapt to development and change.

\section{Unhealthy psychology of minority college students in job hunting.}

Minority college students are in the special stage of life with little social experiences and immature psychology. Once faced with difficulties during job hunting, their young heart will easily get hurt. Unhealthy psychology of minority college students in job hunting are mainly in below three aspects:

\section{High expectation}

Minority college students' pursuit of ideal career and the realization of own value is a proper demand. Besides, it is not only the pure education for students to study in colleges but also the huge investment of capital. "Questionnaires on the cultivation of applied talents in minority nationality" shows that, when asked about the anticipating salaries after graduation, $29 \%$ of boys hope the figure can be from 5000 to 8000 and about $29 \%$ of them even hope their monthly income can be more than 8000. Girls' expectation is much more conservative.

Anxiety and dependent psychology

Some minority college students have finished their study qualified with some professional skills, because they have grown up smoothly without too many difficulties, they are not good at making decisions in problem analyzing and problem solving. They cannot make reasonable decisions according to their own practical situation during the job hunting when facing choices, instead, they are passively depending on parents' and others' suggestions and cannot reach out at the right time. The failure in the job hunting process even worsens their anxiety for success and puts more psychological pressure on themselves. In addition to the cruel recruitment and long time trying, all of these have made them feel more upset, anxious and what's worse, some of them even start suspecting themselves in their own abilities.

\section{Suggestions on ethnic minority talents cultivation}

Faced with the more and more serious situation of minority graduate's employment, government, schools and students should all take relevant measures.

Research the speed and scale of college enrollment, take a review again on the enrollment policy of higher education.

It is not the number of college student and graduates in a certain time a college owns, but the knowledge and capability required for absorbing new technology in different social classes which decides the future development direction of the whole society. Seeing from other countries' experiences, college education is regarded as one of the important means to enter the upper class and large amount of earnings. So the large amount of minority families is willing to bear and accept the high cost for children receiving higher education. But if there is not a broad labor market, there will be too much minority college graduates in various disciplines. In that case, they must look for jobs 
everywhere, some of them even can only stay at home for longtime unemployment. Due to inability to find the job, salary or social status they think they deserve to get, they may get extremely discontent or have nationality emotions, which will affect the political stability and national unity.

The government should provide full policy support for the minority college graduates' employment.

The employment policy of minority college graduates is one part of the national employment policies. The government should speed up making and perfection various policies to guarantee minority college graduates' rights, to promote the healthy development of the employment market and the systematic reforms on personnel system, household registration system, social security systems so as to the normalization and legislation of minority college graduates' employment can be achieved. The government should strengthen the fundamental education in nationality areas, reduce the preferential policies on minority students' recruitment in colleges, but at the same time give more preferential policies on their employment when they graduate from colleges.

\section{Strengthen the ideological and political education to help minority college students to set up correct employment concept.}

Minority college students are motivated by profits and self-esteem when they are hunting jobs and would be more willing to work in places where provides higher salaries and better working environment. But this kind of positions are limited. Thus, we need to educate minority college students on their ideological and political awareness and set up the correct view of employment. By ideological and political education, they can know clearly about the society, and the situation in the whole country and the local region. Fully understanding of the current employment situation in western area can lead them to the places needing help, and make them realize the fact that some basic units and countryside enterprise in poor areas are in urgent demand of talents. Their personal value can be realized if they go there for larger space for development and creation.

Therefore, colleges and universities should locate their position precisely and improve the management. They should combine the regional situation and the school's situation to decide the amount and scale of minority talents cultivation on the basis of scientific speculation from the market demand, then to set up related professional structures, courses and teaching contents for reinforcement of the school reform. Intensify the teach team construction, especially the minority teachers, to improve the teaching quality. Pay more attention to the minority talents cultivation quality, especially the ability of Chinese language expression, communication, innovation and operation to nurture the compound ethnic minority talents adapting to the market economy. Moreover, colleges and universities should instruct more survival knowledge and skills to students, and provide them more fortune-making knowledge and capabilities according to different students' requirement and practical situation. In that case, students can make full use of what they have learned to realize their value of life.

Meanwhile, government, unlike colleges and universities, is under the control of comprehensive information, so they should take the advantage to voluntarily provide necessary information service and guidance and create better environment for ethnic minority talents cultivation.

\section{References}

[1] Cui Lihua, Geng Guihong, Lu Youjun, Exploration on Minority Technology Innovative Talents Cultivation in Colleges. Experimental Technology and Management, 2012(08)

[2] Wang Jian,Zhang Hai, Current Situation and Development Research on Human Resources in Chinese Minority Area. Journal of Northwest Normal University, 2010(06)

[3] Shan Depeng, Reserch on Synchronous Rising of the Economy and Employment in Western Minority Areas . Journal of Ethnology, 2013(02)

[4] Yang Yulan, Experiment and Reform of the Admission Policy of Graduate Students for Nationalities in China. Academic Degrees \&amp; Graduate Education. 2013 (03) 
[5] Qiao Wenzhong, More Love to Minority Students---Southwest College of Engineering's Attention to Ethnic Minority Talents Cultivation. Sichuan United Front, 1998(01) 